\title{
Nucleosides and nucleotides: natural bioactive substances in milk and colostrum
}

\author{
Eckhard Schlimme*, D. Martin and H. Meisel \\ Bundesanstalt für Milchforschung, Institut für Chemie und Physik, Kiel, Germany
}

\begin{abstract}
Nucleotides, nucleosides and nucleobases belong to the non-protein-nitrogen (NPN) fraction of milk. The largest amounts of ribonucleosides and ribonucleotides - ribose forms only were considered in this review - were measured directly after parturition in bovine milk and other ruminants as well as in the milk of humans. Generally, concentrations of most of the nucleos(t)ides tend to decrease gradually with advancing lactation period or nursing time. The species-specific pattern of these minor constituents in milk from different mammals is a remarkable property and confirms, at least, the specific physiological impact of these minor compounds in early life. The physiological capacity of these compounds in milk is given by the total potentially available nucleosides. The main dietary sources of nucleos(t)ides are nucleoproteins and nucleic acids which are converted in the course of intestinal digestion into nucleosides and nucleobases the preferred forms for absorption in the intestine. Thus, nucleosides and nucleobases are suggested to be the acting components of dietary and/or supplemented nucleic acid-related compounds in the gut. They are used by the body as exogenous trophochemical sources and can be important for optimal metabolic functions. Up to $15 \%$ of the total daily need for a breast-fed infant was calculated to come from this dietary source. Concerning their biological role they not only act as metabolites but are also involved as bioactive substances in the regulation of body functions. Dietary nucleotides affect immune modulation, e.g. they enhance antibody responses of infants as shown by a study with more than 300 full-term healthy infants. Dietary nucleos(t)ides are found to contribute to iron absorption in the gut and to influence desaturation and elongation rates in fatty acid synthesis, in particular long-chain polyunsaturated fatty acids in early stages of life. The in vitro modulation of cell proliferation and apoptosis has been described by ribonucleosides, in particular by modified components using human cell culture models. Due to the bio- and trophochemical properties of dietary nucleos $(\mathrm{t})$ ides, the European Commission has allowed the use of supplementation with specific ribonucleotides in the manufacture of infant and follow-on formula. From the technochemical point of view, the ribonucleoside pattern is influenced by thermal treatment of milk. In addition ribonucleosides are useful indicators for quantifying adulterations of milk and milk products.
\end{abstract}

Nucleosides and nucleotides: Bioactive substances: Milk and colostrum

\section{Introduction}

Nucleotides, nucleosides and nucleobases, occurring in the sub-milligram range per litre, belong to the non-proteinnitrogen (NPN) fraction of milk. The terms nucleoside and nucleotide will consider only ribose forms in this review. Although specific compositions of milk ribonucleotides have been described for several mammalian species by different authors since the late 1950s (Manson, 1956; Johke \& Goto, 1962; Larson, 1976; Gil \& Sanchez-Medina,
$1981 a, b)$ and although their role as dietary modulators is of current interest concerning the supplementation of infant formula with individual ribonucleotides (Gil et al. 1988; Commission Directive, 1996), it was only during the last decade that the ribonucleosides have become an object of food research (Tiemeyer et al. 1984; Schlimme et al. 1986, 1991, 1997b; Raezke et al. 1988; Raezke \& Schlimme, 1990; Groß et al. 1992; Schneehagen \& Schlimme, 1992; Topp et al. 1993; Schlimme \& Schneehagen, 1995). The species-specific concentration pattern of

\footnotetext{
Abbreviations: Ado, adenosine; m1Ado, 1-methyladenosine; m6Ado, N6-methyladenosine; m6,2Ado, N6-dimethyladenosine; ip6Ado, N6-(2isopentenyl)-adenosine; t6Ado, N6-carbamoyl-L-threonyladenosine; Guo, guanosine; m1Guo, 1-methylguanosine; m7Guo, 7-methylguanosine; m2Guo, N2-methylguanosine; m2,2Guo, N2-dimethylguanosine; Cyd, cytidine; Ino, inosine; m1Ino, 1-methylinosine; m7Ino, 7-methylinosine; Urd, uridine; $\psi$, pseudouridine; 5'-AMP, adenosine- $5^{\prime}$-monophosphate; $5^{\prime}$-CMP, cytidine- $5^{\prime}$-monophosphate; $5^{\prime}$-GMP, guanosine-5'-monophosphate; $5^{\prime}$-IMP, inosine-5'-monophosphate; $5^{\prime}$-UMP, uridine-5'-monophosphate.
}

* Corresponding author: Professor E. Schlimme, fax +49431 609-2300, email schlimme@bafm.de 
Table 1. Ribonucleosides $\left(\mu \mathrm{mol} / \mathrm{l}^{*}\right.$ in bovine milk and colostrum

\begin{tabular}{lrrrrrrrc}
\hline & Ado & Cyd & Guo & Ino & Urd & m1Ado & t6Ado & Ado+Ino \\
\hline $\mathrm{C}_{7}{ }^{\mathrm{a}}$ & 2.0 & 11.6 & 2.1 & 4.7 & 132.6 & 1.0 & 2.9 & 6.7 \\
$\mathrm{C}_{14}{ }^{\mathrm{b}}$ & 2.6 & 6.0 & 2.0 & 2.9 & 58.2 & 0.5 & 1.1 & 5.5 \\
$\mathrm{C}_{21}{ }^{\mathrm{c}}$ & 2.4 & 4.0 & 1.5 & 1.5 & 25.6 & 0.5 & 0.8 & 3.9 \\
$\mathrm{C}^{\mathrm{d}}$ & 1.4 & 2.4 & 0.8 & 1.0 & 14.7 & 0.4 & 0.7 & 2.4
\end{tabular}

* Values taken from Raezke \& Schlimme (1990), details with respect to the automated operation of the ribonucleoside analyzer are described elsewhere (Raezke \& Schlimme, 1990; Schlimme \& Boos, 1990; Schlimme et al. 1991). Each mean value is the arithmetic mean of determinations (in duplicate) in the first (a), second (b) and third (c) lactation week postpartum as well as throughout the whole lactation period with the exception of the first 3 weeks postpartum (d).

the milk constituents shows the species-specific physiological relevance of these minor compounds for the neonate. It is generally taken for granted that these species-specific concentration patterns are physiologically relevant as otherwise the evolutional process would have resulted in elimination of the species-specific pattern of this substance group.

\section{Compositional aspects}

\section{Ribonucleosides}

A reported study on the concentration levels and pattern of ribonucleosides in raw bovine milk throughout a lactation period under defined feeding conditions has shown that, with the exception of the colostral phase, the levels of these minor milk constituents vary only slightly (Raezke \& Schlimme, 1990; Schlimme et al. 1991). From all measured values for a given ribonucleoside it appears that the nucleoside concentration decreases during the colostral phase and reaches a constant level approximately three weeks postpartum (Table 1). In comparison to Gil \& Sanchez-Medina's $(1981 a, b)$ findings on nucleotides in bovine milk, no distinct maximum concentration of the nucleosides was observed during the first two days after parturition (Raezke \& Schlimme, 1990; Schlimme et al. 1991).

In the colostral phase the ribonucleoside contents in milk exceeded markedly the mean content established throughout lactation (Table 1). In contrast to the unmodified ribonucleosides, the modified components m1Ado and t6Ado showed this pronounced dependence on lactation only in the first week of lactation. The rather high ribonucleoside concentrations - particularly of uridine in colostral milk provokes questions about the lactobiochemical causes of this finding. It remains to be clarified, for example, whether the origin of milk ribonucleoside is humoral and/or local. In the first case, ribonucleosides penetrate from blood into milk via the blood-milk barrier (Ziv \& Sulman, 1975; Larson et al. 1980; Ziv \& Heavner, 1984); in the second case they result from metabolic processes in the mammary gland and are excreted from the lactating cell into the alveolar lumen or formed by postsecretory metabolic processes in milk. Thus the high metabolic activity of the mammary gland should be considered along with the increased transfer rate of the ribonucleosides circulating in the blood through the blood- milk barrier in the first days postpartum. During this period the colostrum contains a high proportion of blood constituents (Larson et al. 1980). Postsecretory metabolic processes attributable to milk enzymes (e.g. alkaline phosphatase, adenosine deaminase), somatic cells, and micro-organisms are markedly pronounced in colostral milk (Schlimme et al. 1991; Martin et al. 1997).

Tiemeyer et al. (1984) have reported uridine and cytidine concentrations, respectively, five and two times larger than those summarized in Table 1. These anomalies may be explained by differences in the methods used. The method (Tiemeyer et al. 1984) involves an elaborate and manually performed sample pretreatment, which may allow enough time for postsecretory conversions to occur (Schlimme et al. 1991; Martin et al. 1997).

On examining the results for mature bovine milk, it is striking that the concentrations of the pyrimidine ribonucleosides are about $17 \mu \mathrm{mol} / \mathrm{l}$, i.e. approximately fivefold greater than those of the purine ribonucleosides (about $3 \mu \mathrm{mol} / \mathrm{l})$. This reflects, among other things, the lactobiochemical importance of uracil ribonucleotides, e.g. UDPhexoses for lactose biosynthesis in the mammary gland. The results of ribonucleoside analyses in bovine milk at different stages of lactation, including the colostrum phase, agree with findings by Gil \& Sanchez-Medina $(1981 a, b)$ of rather large contents - up to $0.3 \mathrm{mmol} / \mathrm{l}$ - of UDP-glucose and UDP-galactose, mainly during the colostral phase. Therefore, the previously observed (Raezke \& Schlimme, 1990; Schlimme et al. 1991) tenfold increased concentration of uridine (about $0.1 \mathrm{mmol} / \mathrm{l}$ ) during the first week of lactation (Table 1) is not surprising.

In contrast to bovine milk, the concentrations of the pyrimidine and the purine ribonucleosides are almost equal in goat milk (Schlimme et al. 1991). The concentration of purine nucleosides $(17 \mu \mathrm{mol} / \mathrm{l})$ in goat milk is fivefold greater than in bovine milk. These results correlate with those described for the nucleotide contents of goat and bovine milk (Gil \& Sanchez-Medina, 1981a,b).

The composition of ribonucleosides in human milk differs from that found in the milk of ruminants not only quantitatively but also qualitatively (Groß et al. 1992; Schneehagen \& Schlimme, 1992; Topp et al. 1993; Schlimme \& Schneehagen, 1995; Schlimme et al. 1996a, 1997b). Interindividual mean values of eight ribonucleosides quantified during mature stages of lactation are given in Table 2. The concentration profiles of the nucleosides

Table 2. Ribonucleosides in mature human milk

\begin{tabular}{lcccccccc}
\hline & Ado & Cyd & Guo & Urd & m1Ado & t6Ado & m1Guo & $\psi$ \\
\hline$\mu \mathrm{mol} / /^{*}$ & 5.3 & 4.3 & 0.2 & 0.5 & 0.3 & 0.5 & 0.4 & 1.7 \\
$\mathrm{mg} / \mathrm{l}$ & 1.4 & 1.0 & 0.1 & 0.1 & 0.1 & 0.2 & 0.1 & 0.4 \\
$\mu \mathrm{mol} / \mathrm{l} \dagger$ & 1.6 & 4.4 & 0.3 & 6.9 & $-\S$ & - & - & - \\
$\mathrm{mg} / \mathrm{l}$ & 0.4 & 1.1 & 0.1 & 1.7 & - & - & - & - \\
$\mu \mathrm{mol} / \mathrm{l} \neq$ & 3.0 & 5.1 & 1.0 & 4.2 & 0.3 & 0.4 & 0.7 & - \\
$\mathrm{mg} / \mathrm{l}$ & 0.8 & 1.2 & 0.3 & 1.0 & 0.1 & 0.2 & 0.2 & -
\end{tabular}

* Adapted from Topp et al. (1993); values reported on m2Guo, m2,2Guo and $\mathrm{m} 1 \mathrm{lno}$, respectively, were all $<0.1 \mu \mathrm{mol} / \mathrm{l}$.

$\dagger$ Adapted from Leach et al. (1995).

$\ddagger$ Adapted from Schneehagen \& Schlimme (1992), Schlimme \& Schneehagen (1995).

$\S$ - no data published.

All values rounded to one decimal place. 
Table 3. Ribonucleotides $(\mu \mathrm{mol} /)^{*}$ in bovine milk at different stages of lactation

\begin{tabular}{lccccc}
\hline & \multicolumn{5}{c}{ Time postpartum } \\
\cline { 2 - 6 } & 0-1 d & $1-2 \mathrm{~d}$ & 5-10 d & 1 month & 2 months \\
\hline 5'-AMP & 39.7 & 61.8 & 41.9 & 27.5 & 20.3 \\
5'-CMP & 31.9 & 52.5 & 47.4 & 33.2 & 18.9 \\
5'-GMP & n.d. & n.d. & n.d. & n.d. & n.d. \\
5'-UMP & 186.3 & 390.0 & 31.2 & n.d. & n.d. \\
\hline
\end{tabular}

n.d., not detectable.

*Values taken from Gil \& Sanchez-Medina (1981a).

tend to decrease without distinct maximum values in the course of lactation (Schlimme \& Schneehagen, 1995).

\section{Ribonucleotides}

Common ribonucleotide contents in cow's milk at different stages of lactation have been measured after isolation by ion-exchange chromatography followed by postcolumn enzymic characterization of pooled chromatographic fractions (Gil \& Sanchez-Medina, 1981a). Table 3 presents the levels of some common ribonucleoside- $5^{\prime}$-monophosphates such as $5^{\prime}$-AMP, 5'-CMP, 5'-GMP and $5^{\prime}$-UMP found at different periods postpartum (Gil \& Sanchez-Medina, 1981a). A few hours after parturition ( $2 \mathrm{~h}$ ) a very low content of ribonucleotides was found, whereas after about 1 day postpartum $(27 \mathrm{~h})$ the ribonucleotide contents reached a maximum which decreased gradually as lactation continued (Gil \& Sanchez-Medina, 1981a,b). This pattern is also valid with regard to the total amount of ribonucleotides, i.e. including ribonucleoside-5'-mono-, di- and triphosphates $\left(\Sigma \mathrm{A}_{\mathrm{t}}, \quad \Sigma \mathrm{C}_{\mathrm{t}}, \quad \Sigma \mathrm{G}_{\mathrm{t}}, \quad \Sigma \mathrm{U}_{\mathrm{t}}\right)$ as well as UDPgalactose and -glucose (Gil \& Sanchez-Medina, 1981b). At two days postpartum the following concentration levels ( $\mu$ mol/l) have been described: $\Sigma \mathrm{A}_{\mathrm{t}}=67 \cdot 8, \Sigma \mathrm{C}_{\mathrm{t}}=60 \cdot 5$, $\Sigma \mathrm{G}_{\mathrm{t}}=36 \cdot 5, \Sigma \mathrm{U}_{\mathrm{t}}=1495 \cdot 0, \mathrm{UDP}$-galactose $=320 \cdot 2, \mathrm{UDP}-$ glucose $=362 \cdot 3$. Orotic acid is the main nucleotide-related compound in bovine milk, its concentration increases with advancing lactation by about one order of magnitude and reaches a level of about $400 \mu \mathrm{mol} / 16$ months after parturition (Gil \& Sanchez-Medina, 1981b).

The concentration of common ribonucleotides is about one to two orders of magnitude higher than that of common ribonucleosides (Gil \& Sanchez-Medina, 1981a; Raezke \& Schlimme, 1990; Schlimme et al. 1991). 5'-AMP and 5'CMP have been found to be present in all milk samples from colostral to mature stages of lactation, whereas $5^{\prime}$ UMP has not been detected later than 3 weeks post partum. $5^{\prime}$-GMP has been reported to be practically absent from bovine milk. The results reported by Gil \& SanchezMedina (1981a) agree with former findings described, e.g. by Johke \& Goto (1962).

Nucleotides were isolated from human milk for the first time in the early 1960s (Deutsch \& Nilsson, 1960; Kobata, 1963). Widely fluctuating concentrations of ribonucleotides (4-70 mg/l corresponding to 10-200 $\mu \mathrm{mol} / \mathrm{l}$ ) have been reported from subsequent studies (Deutsch \& Nilsson, 1960; Kobata, 1963; Gil \& Sanchez-Medina, 1982; Janas \& Picciano, 1982), in part at least dependent on different
Table 4. Ribonucleotides in mature human milk*

\begin{tabular}{lcccc}
\hline & $5^{\prime}$-AMP & $5^{\prime}$-CMP & $5^{\prime}$-GMP & $5^{\prime}$-UMP \\
\hline$\mu \mathrm{mol} / \mathrm{l} \dagger$ & 20 & 19 & 3 & 13 \\
$\mathrm{mg} / \mathrm{l}$ & 7.8 & 7.0 & 1.2 & 4.8 \\
\hline
\end{tabular}

* Adapted from Gil \& Sanchez-Medina (1982).

$\dagger 1$ month postpartum; values given as disodium salt.

analytical procedures used for quantification. Gil \& Sanchez-Medina (1982) give concentration data found for ribonucleotides at different stages of lactation in human milk (Table 4). Most of the data show that cytosine and uracil nucleotides comprise the largest fractions of the nucleotide content. These findings agree well with the ribonucleoside pattern (Table 2). Gil \& Sanchez-Medina (1982) report on contents of UDP-galactose and -glucose which are about $10 \mu \mathrm{mol} / \mathrm{l}$ for both UDP-sugars and vary only slightly throughout lactation. All in all, the total ribonucleotide content is higher in human than in ruminant milk (Molina et al. 1996). Orotic acid is present in the milk of ruminants but not in human milk.

Although nucleoside and nucleotide analyses have been performed for years, there are only a small number of studies that have collected quantitative data about all the nucleot(s)ide sources, as there are nucleoproteins, nucleic acids and nucleot(s)ide derivatives, including coenzymes, which can all contribute to the nucleot(s)ide content in body fluids. Leach et al. (1995) have defined the nucleoside content, analytically accessible via the aforementioned approaches, as the 'total potentially available nucleosides' TPAN (Table 5). The mean contents of individual nucleosides in colostrum, transitory and mature human milk from 100 women in childbed from Europe (Germany, France, Italy) were taken into account at establishing the mean value (Leach et al. 1995). In the USA the mean values of the four nucleosides of eleven women in childbed were found by Leach et al. (1995) to be within the variation limit of the European proband collective.

In Table 5, in addition to ribonucleosides and ribonucleotides, the TPAN values for human milk (Leach et al. 1995) are represented, including the contents of ribonucleot(s)ides and of oligo- and polymeric ribonucleic acids (RNA). The TPAN content, partially stemming from ribonucleic acids, was significantly different with regard to the four individual nucleosides, and reflected above all the relevance of adenine nucleotides in bioenergetics and biosynthesis. Inosine was detected in human milk in concentrations one order of magnitude smaller than that of the TPAN contents of the other four nucleosides. In most of the milk samples no inosine was found (Leach et al.

Table 5. Ribonucleosides, ribonucleotides and 'total potentially available ribonucleosides (TPAN)' ( $\mu \mathrm{mol} / \mathrm{l})$ in human milk

\begin{tabular}{lccccc}
\hline & Ado & Cyd & Guo & Urd & TPAN \\
\hline Ribonucleosides $^{*}$ & 3 & 5 & 1 & 4 & - \\
Ribonucleotides $†$ & 20 & 19 & 3 & 13 & - \\
TPAN $\neq$ & 32 & 88 & 31 & 38 & 189 \\
\hline
\end{tabular}

Values (rounded to the nearest whole number) taken from: *Schlimme \& Schneehagen (1995); †Gil \& Sanchez-Medina (1982); †Leach et al. (1995). 
1995). These results are confirmed by investigations of Japanese human milk samples, in which $5^{\prime}$-GMP and 5'IMP could only be detected in a few samples (Sugawara $e t$ al. 1995).

Based on the presented results, the quantity of nucleotides or nucleosides to be added to infant formula to obtain TPAN contents similar to those in mature human milk can be evaluated. This would allow the advantageous properties of nucleot(s)ides would be made available to non-breastfed infants via ingestion of supplemented infant formula (see below).

For a better evaluation of the concentration level of ribonucleosides in human milk (Table 2) the nutrient density $(\mu \mathrm{g} / \mathrm{MJ})$ of these minor compounds should be compared to that of certain vitamins in milk: vitamin A (239) (Souci et al. 1994), adenosine (278), cytidine (417), nicotinamide (589) (Souci et al. 1994).

\section{Trophochemical aspects}

Nucleotides play key roles in nearly all biochemical processes in cell metabolism and are the monomeric precursors of nucleic acids. Nucleotides are provided by either endogenous biochemical sources - de novo synthesis and/or salvage pathway - or by exogenous trophochemical sources, i.e. by dietary supply.

Dietary nucleotides are ingested mainly as nucleoproteins (Uauy, 1989, Uauy et al. 1996) and are converted in the course of intestinal digestion into monomeric compounds. Nucleosides and nucleobases are translocated across the plasma membrane by specified facilitateddiffusion carriers and sodium-dependent transporters (Plagemann \& Wohlheuter, 1984; Aronow et al. 1986; Bronk \& Hastewell, 1987; Ullman et al. 1987; Belt \& Noel, 1998; Vijayalakshmi et al. 1992; Griffith \& Jarvis, 1993; Jarvis, 1996) located in intestinal and kidney epithelial cells (Le Hir \& Dubach, 1985; Darnowski et al. 1987; Lee et al. 1988; Jarvis, 1989; Williams \& Jarvis, 1991; Gutiérrez et al. 1992). When nucleoproteins and/or nucleotides are fed, there is evidence that the gut will activate the transcription of enzymes responsible for the salvage pathway, in particular in the upper intestine. It is known that some tissues such as the intestinal mucosa and bone haematopoietic cells preferentially utilize the salvage pathway due to limited capacity for de novo synthesis (Uauy, 1989), i.e. for these cells the exogenous supply of nucleic acid derived components can be important for optimal functions. From this view nucleotides and related compounds have been recognized to be semiessential (Uauy, 1989; Molina et al. 1996).

Uauy (1989) has calculated to what extent preformed dietary nucleotides can cover the total body need of these components. He has estimated a nucleotide pool of 9-15 g per $\mathrm{kg}$ body weight of a full-term newborn. Considering a daily growth rate of $10 \mathrm{~g} / \mathrm{kg}$ an accretion rate of total nucleotides for a $3 \mathrm{~kg}$ infant would be approximately $12 \mathrm{mg}$ nucleotides per $\mathrm{g}$ body weight gain. The ingestion of milk nucleotides for a breast-fed newborn was calculated to be less than $2 \%$ of daily needs and up to $15 \%$, if dietary nucleic acids are considered (Uauy, 1989). Uauy (1989) concluded that "nucleotides may have potential effects on gut and related tissues, which would be most important to their influence, but would not be likely to have systemic effects given the very small contribution of dietary supply to overall nucleotide economy'.

The presence of specific nucleos(t)ides in human milk may be a factor in the immune response of breast-fed infants (Gyorgy, 1971) and are suggested as growth factors for the neonate (Barness \& Carver, 1996). However, clinical studies with nucleotide supplemented formula have not shown detectable effects on weight gain, linear growth and other anthropometric indices of growth (Uauy, 1989 and cited references).

In this context Pickering et al. (1998) investigated whether human milk and ribonucleotides added to infant formula at levels present in human milk enhance infant immunity as measured by antibody response to immunization. A total of 370 full-term healthy infants were enrolled in the study. They were divided into three groups for a period of 12 months; 311 infants (84\%) completed the study. The control group (125/107 infants, $46 \%$ female) were given a milk-based control formula and the nucleotide group $(121 / 101 ; 42 \%$ female) the same formula fortified with $73 \mathrm{mg}$ nucleotides/l. The target level of fortification was based on that of human milk (Leach et al. 1995) and was adjusted to $31.2 \mathrm{mg} 5^{\prime}$-CMP; $17.7 \mathrm{mg} 5^{\prime}$-UMP, $9.8 \mathrm{mg} 5^{\prime}$-AMP, and $14.4 \mathrm{mg} 5^{\prime}$-GMP per litre in the nucleotide formula (see Table 6 ). The third group were fed human milk (124/103; $54 \%$ female) for 2 months and then further on exclusively human milk or Similac ${ }^{\circledR}$-formula with iron (Ross Lab., Columbus, USA) until 12 months of age. As a parameter for the development of the infants' immune system the vaccination reaction was followed up for the first year of life. According to specifications of the American Academy of Pediatrics, the vaccinations against infections by Haemophilus influenzae, diphtheria, tetanus and oral polio virus were performed at the ages of 2, 4 and 6 months. During the sixth, seventh and twelfth months the antibody responses were determined. The Pickering et al. (1998) study closed with the following conclusion: 'Infant formula fortified with nucleotides enhanced Haemophilus influenzae and diphtheria humoral antibody responses. Feeding human milk caused an enhanced antibody response to oral polio virus.'

The aforementioned study collected data on diarrhoea illness and showed that the ingestion of nucleotide-fortified formula or human milk was associated with a significant decrease in the incidence of diarrhoea when compared to the control group (Pickering et al. 1998).

Futhermore, a series of clinical studies on adults investigated the effects of RNA supplemented enteral food in comparison with RNA-free food. These studies were primarily performed by van Buren \& Rudolph (1997) and resulted in the findings that optimal patient outcome may depend on provision of dietary nucleotides during a period of stress. These data support the conclusion that dietary nucleotides are conditionally essential nutrients. In this context, a publication by Fairbairn \& Litt (1922) is of interest. The paper reports on a successful subcutaneous application of Nuclein (nucleic acid) in the case of different infections showing that this compound is a valuable adjunct to other treatment of infection. 
Table 6. Comparison of the supplemented quantity of nucleotides in infant formula according to the EC Directive, the nucleotide group (Pickering et al. 1998) and the supplementation recommendation (Schlimme \& Martin, 1999) based on TPAN contents in human milk (Leach et al. 1995)

\begin{tabular}{|c|c|c|c|c|c|c|c|}
\hline Reference & $5^{\prime}$-AMP & $5^{\prime}-\mathrm{CMP}$ & $5^{\prime}-\mathrm{GMP}$ & $5^{\prime}$-UMP & $5^{\prime}-\mathrm{IMP}$ & Total & Upper limit \\
\hline \multicolumn{8}{|l|}{ Commission Directive, (1996) } \\
\hline$(\mathrm{mg} / 100 \mathrm{kcal})$ & 1.50 & 2.50 & 0.50 & 1.75 & 1.00 & 7.25 & 5 \\
\hline $\begin{array}{l}(\mathrm{mg} / \mathrm{l})^{\star} \\
\text { Pickering et al. (1998) }\end{array}$ & 10.4 & 17.3 & 3.5 & 12.1 & 6.9 & 50.2 & (35) \\
\hline $\begin{array}{l}(\mathrm{mg} / \mathrm{l}) \\
\text { Schlimme \& Martin (1999) }\end{array}$ & 9.8 & 31.2 & 14.4 & 17.7 & $-\dagger$ & 73.1 & $-†$ \\
\hline (mg/100 kcal) & 1.8 & 4.7 & 1.8 & 2.0 & $-\ddagger$ & 10.3 & $-\ddagger$ \\
\hline$(\mathrm{mg} / \mathrm{l})^{\star}$ & 12.5 & 32.3 & 12.6 & 14.0 & $-\ddagger$ & 71.4 & $-\ddagger$ \\
\hline
\end{tabular}

* The conversion on mg nucleotide/l infant formula was calculated under the assumption that the infant formula used is isocaloric with human milk (69 $\mathrm{kcal} / 100 \mathrm{~g}$ milk according to Souci et al. 1994); nucleotide values are given as disodium salt.

$\dagger$ Without addition of $5^{\prime}$-IMP.

$\ddagger$ Not recommended.

Due to the trophochemical properties of dietary nucleos(t)ides, the supplementation of infant formula and follow-on formula with nucleotides has been used for many years in some member states of the European Union as well as in third-world countries. As no negative effects related to the nucleotide supplementation are known the Commission Directive 96/4/EC (1996) allows the supplementation of infant formula with nucleotides according to concentrations given in Table 6 (Commission Directive, 1996).

Supplementation of infant formula with nucleotides and/ or nucleosides should be allowed up to levels present in human milk. In evaluating the physiological capacity of nucleosides Leach et al. (1995) reported experimental findings concerning the TPAN including all mono-, oligoand polymeric sources available in milk for the generation of these compounds via digestion and metabolism (values are given in Table 5). 5'-IMP, which was not used for nucleotide supplementation of infant formula in the Pickering et al. (1998) study, is also not mentioned in a recent recommendation (Schlimme \& Martin, 1999, Table 6) due to its low TPAN portion (Leach et al. 1995).

Regarding the supplemention of infant formula with nucleotides it should be noted that the current EC Regulation (the 'Life Science Research Office' of the USA is working on a corresponding regulation) takes into account only those unmodified milk nucleotides that are released from mono-, oligo- and polymers during digestion and metabolism. It has not been considered that the whole TPAN content of human milk also includes the modified nucleot(s)ides that can be released in RNA breakdown reactions. The regulative potential of modified nucleosides seems to be prospective but is mainly unexplored.

\section{Biochemical aspects}

The need for nucleosides and nucleotides for chemical processes in biological systems is met by a combination of de novo synthesis and reutilization of these compounds by the salvage pathway. Whereas some systems, such as liver cells, have highly active de novo purine and pyrimidine nucleotide synthesis, other systems, such as gut epithelial cells, have limited capacity for de novo synthesis (Uauy, 1989; Uauy et al. 1990). Uauy et al. (1990) demonstrated that dietary nucleosides are able to enhance gut growth and maturation of the weanling rat. In particular, the formation of mucosal protein and mucosal DNA was found to be more pronounced in the proximal segment and the villi in this gut segment to be taller in the nucleoside-fed animal group (Uauy, 1989; Uauy et al. 1990). Furthermore, the ratio of the enzymes maltase (EC 3.2.1.20) and lactase (EC 3.2.1.23), which is an index for gut maturation, was increased in the nucleoside supplemented group (Uauy et al. 1990). Leleiko et al. (1979, 1983, 1987) have described the effect of dietary nucleosides on the activity of the enzyme hypoxanthine-guanine phosphoribosyltransferase (HGPRT) in the small intestine of rats. HGPRT is the ratelimiting enzyme in the salvage pathway of purine nucleotides (Leleiko et al. 1979, 1983, 1987; Uauy et al. 1990). Diets free from purine nucleosides and bases lower the intestinal HGPRT activity and decrease the level of messenger RNA of this salvage pathway related key enzyme (Uauy et al. 1990).

Mice fed ad libitum on chow plus water supplemented with nucleotides $(3.5 \mathrm{mg} / 100 \mathrm{ml})$ for six weeks have been shown to exhibit increased natural killer cell (NK) activity in the spleen and lower macrophage activation compared to mice receiving chow alone (Carver et al. 1990). The biological effects found need further investigation to get more insight into the molecular processes induced by dietary nucleos $(\mathrm{t})$ ides. From experimental findings of Barness' group (Carver et al. 1990; Barness \& Carver, 1996) it is known that infants fed with a formula supplemented with nucleotides ( $5^{\prime}$-AMP, $4 \mathrm{mg} / \mathrm{l} ; 5^{\prime}$-CMP, $20 \mathrm{mg} / \mathrm{l} ; 5^{\prime}$-GMP, $2 \mathrm{mg} / \mathrm{l}$; $5^{\prime}$-UMP, $5 \mathrm{mg} / \mathrm{l} ; 5^{\prime}$-IMP, $2 \mathrm{mg} /$ 1) show (in contrast to infants fed the same formula without nucleotide supplement) an immune response (natural killer cells, interleukin-2) similar to the immunological effect in breast-fed infants. These data suggest these normal milk constituents may be physiologically important.

It has been suggested that nucleos(t)ides contribute to iron absorption in the gut (McMillan et al. 1977). It was found that inosine increases intestinal uptake of iron in rats (Faelli \& Esposito, 1970). Thus human milk 'may be a factor in facilitating iron absorption in breast-fed infants' (McMillan et al. 1977). Dietary nucleotides may also be involved in lipid metabolism (Sanchez-Pozo et al. 1986; Sanchez-Pozo \& Gil, 1996) by stimulating $\alpha$-lipoprotein synthesis. Plasma levels of major lipoprotein fractions have been studied in different groups of newborn infants (e.g. preterm, full-term neonates) fed on formula with and 
without supplementation of nucleotides (Sanchez-Pozo \& Gil, 1996). From their experimental findings Sanchez-Pozo \& Gil (1996) concluded that 'dietary nucleotides may have a positive effect on the lipoprotein metabolism of newborns by increasing HDL synthesis'. Long-chain polyunsaturated fatty acids (LC-PUFA) such as arachidonic, eicosapentaenoic and docosahexaenoic acids are important compounds in cell membrane structure. LC-PUFA are present in adequate amounts in human milk but not in adapted cowmilk-based formula. At-term infants fed with formula have lower amounts of LC-PUFA-levels in plasma, and their concentration in red blood cell membrane phospholipids has been shown to be lower than in breast-fed infants (Putnam et al. 1982; Carlson et al. 1986, 1987; Koletzko et al. 1989; Sanchez-Medina \& Gil, 1996). After supplementation of the formula with nucleotides an increase of LCPUFA in the plasma and red blood cells was observed (Gil et al. 1986, 1988; DeLucchi et al. 1987; Sanchez-Medina \& Gil, 1996). Very probably these effects are related to an influence of dietary nucleotides on desaturation and elongation rates in fatty acid metabolism (Pita et al. 1988). The in vitro and in vivo influences of nucleos(t)ides on liver regeneration have been reported. Five kinds of nucleic acid components - inosine, cytidine, uridine, thymidine and 5'-GMP - were studied in monolayer cultures of hepatocytes concerning their effects on DNA and RNA synthesis. The results reported by Ohyanogi et al. (1996) confirmed the importance of nucleos(t)ides in enhancing nucleic acid metabolism depending on each individual component and suitable concentrations.

The in vitro modulation of cell proliferation and apoptosis (for review see Martin et al. 1994) by individual

Table 7. Comparison of modulating effects of ribonucleosides $\left(10^{-3} \mathrm{~mol} / \mathrm{l}\right)$ on cell proliferation and apoptosis assayed by quantitative immunoassay based on BrdU incorporation and DNA fragmentation in cell lysates, respectively†

\begin{tabular}{|c|c|c|c|c|}
\hline \multirow{2}{*}{ Ribonucleoside } & \multicolumn{2}{|c|}{ Proliferation } & \multicolumn{2}{|c|}{ Apoptosis } \\
\hline & HL-60 & Caco-2 & HL-60 & Caco-2 \\
\hline Ado & $0.21^{\star \star \star a}$ & 0.96 & $4.91^{\star \star \star}$ & 1.25 \\
\hline m1Ado & $0.07^{\star \star \star b}$ & $0.72^{\star \star \star}$ & 0.92 & $1.37^{\star *}$ \\
\hline m6Ado & $1.17^{\star \star \star b}$ & $0.61^{\star \star \star}$ & $1.37^{\star *}$ & $1.34^{\star *}$ \\
\hline m6,2Ado & $0.00^{\star \star \star c}$ & $0.01^{\star \star \star a}$ & $14.11^{\star * *}$ & $5.28^{\star \star *}$ \\
\hline ip6Ado & $0.01^{\star \star \star c}$ & $0.01^{\star \star \star a}$ & $21.90^{\star \star *}$ & 1.51 \\
\hline t6Ado & 0.92 & 0.96 & 1.18 & 1.08 \\
\hline Guo & $0.61^{\star *}$ & $0.89^{\star \star}$ & 2.00 & $2.08^{\star \star \star d}$ \\
\hline m1Guo & 0.97 & $0.88^{\star \star \star}$ & 1.42 & 0.90 \\
\hline m2Guo & $1.24^{\star}$ & 1.01 & 1.58 & $1.31^{\star \star}$ \\
\hline m2,2Guo & $0.01^{\star \star \star}$ & $0.90^{\star \star}$ & $4.56^{\star \star \star}$ & 0.88 \\
\hline m7Guo & 1.26 & 1.04 & 1.71 & 1.13 \\
\hline Ino & 1.09 & 1.01 & 1.22 & 1.08 \\
\hline m1lno & 1.16 & 0.98 & 1.22 & 0.97 \\
\hline m7Ino & $0.75^{\star}$ & 1.03 & 1.64 & 0.94 \\
\hline Cyd & 0.59 & $0.81^{\star \star \star}$ & 1.70 & 0.88 \\
\hline Urd & 1.17 & 0.87 & 1.23 & 0.97 \\
\hline
\end{tabular}

† Results are expressed as the ratios test/control (mean absorbance test $_{\text {mean }}$

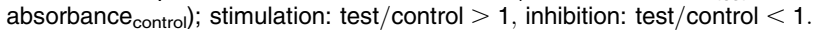
Mean values of measurements differ with ${ }^{*} P<0.05 ;{ }^{* \star} P<0.01$; ${ }^{* \star *} P<0.001$

Significant effect already measurable at ribonucleoside concentration of ${ }^{\mathrm{a}} 10^{-4},{ }^{\mathrm{b}} 10^{-5},{ }^{\mathrm{c}} 10^{-6} \mathrm{~mol} / \mathrm{l}, \mathrm{d}$ Accompanied by significant necrosis based on the measurement of DNA fragments in cell culture supernatant (test $/$ control $=1.55, P<0.05$ )

Values taken from Meisel et al. (1998). ribonucleosides has been investigated by Meisel et al. (1998, 1999) using peripheral blood lymphocytes (PBL), HL-60 cells (promyelocytic leukaemia) and Caco-2 cells (colon adenocarcinoma) as human cell culture models. Modulating effects of several ribonucleosides were found in the range of $10^{-7}$ to $10^{-3} \mathrm{~mol} / \mathrm{l}$. The millimolar concentration was the most effective dosage of all ribonucleosides studied (Table 7). The following ribonucleosides had a marked inhibitory effect on proliferation of PBL and HL-60 cells (Meisel et al. 1998): Ado, m1Ado, m6Ado, m6,2Ado, ip6Ado, m2,2Guo. Except for m1Ado, these ribonucleosides also induced apoptosis of HL-60 cells. A significant apoptotic effect on PBL was found with m6,2Ado and ip6Ado. It is noteworthy that the antiproliferative effect in HL-60 cells, and to some extent the enhancement of apoptosis, revealed a relationship between increasing cell reactivity and the degree of chemical modification of the adenine entity (Table 7) (Meisel et al. 1998). Regarding Caco-2 cell activity, m1Ado, m6Ado, m6,2Ado, ip6Ado and Guo had a pronounced effect as stimulants of apoptosis as well as inhibitors of proliferation. m2Guo induced significant apoptosis of Caco-2 cells but proliferation remained unchanged (Table 7). There is increasing evidence that apoptosis and necrosis represent the extreme ends of a wide range of possible morphological and biochemical deaths (Leist \& Nicotera, 1997). The two classical types of cell death can occur simultaneously in cell cultures exposed to the same stimulus. The mode of cell death induced by Ado and several modified ribonucleosides was apoptotic.

To elucidate the possible mechanisms underlying the apoptosis-inducing activities of ribonucleosides, the timedependent utilization at the extra- and intracellular level and the possibility of a receptor-mediated induction of apoptosis was recently investigated (Meisel et al. 1998). It has been found that ribonucleosides can modulate apoptosis of HL-60 cells via different mechanisms. Ado may follow at least two different pathways in triggering apoptosis of HL-60 cells: (1) mainly through entry into cells mediated by nucleoside transporter and direct activation of as yet unidentified intracellular events; and (2) partially through activation of extracellular $\mathrm{A}_{2 \mathrm{~A}}$-like receptors. Modulation of apoptosis by ip6Ado seems to involve an as yet unidentified extracellular receptor-mediated mechanism. It is not yet clear if an $\mathrm{A}_{3}$ receptor-mediated apoptotic pathway contributes to Ado- or ip6Ado-induced cell death.

It is worth noting that the cancer cell lines HL-60 and Caco-2 were more reactive to apoptotic stimulation than non-malignant PBL (Meisel et al. 1998). Most anticancer drugs produce apoptosis in sensitive cells (Hickman, 1992) involving an increased apoptotic response of cancerous cells and a minimal response from normal cells. For example, micromolar concentrations of purine nucleoside analogues (2-chloro- 2 '-deoxyadenosine, 9- $\beta$-D-arabinosyl2-fluoroadenine) are reported to be effective as apoptosisinducing chemotherapeutic agents in the treatment of several types of leukaemia, and it has been shown that their mechanisms of action implicate cellular signalling networks (Robertson et al. 1993).

Regarding the natural presence in living systems, modified ribonucleosides are mainly found in transfer 
RNA and originate from cellular RNA breakdown. It is known that the pattern of these metabolic products is altered in body fluids of individuals suffering from neoplastic diseases, i.e. modified ribonucleosides serve as pathobiochemical marker molecules for cancer (Borek, 1971; Gehrke \& Kuo, 1990; Schlimme et al. 1990a; Schwarzenau et al. 1990). As a vast majority of tumour promoters are potent inhibitors of apoptosis (Wright et al. 1994), it seems unlikely that cancer cells as such produce apoptosis-inducing ribonucleosides. It remains to be clarified if they are released by healthy cells as a reaction against malignant cells. However, this hypothesis is supported by our findings that cancer cell lines (HL-60, Caco-2) are reactive to apoptotic stimulation by modified ribonucleosides (Meisel et al. 1998).

Food-derived inducers of apoptosis may be of significance as exogenous anticarcinogens in the control of malignant cell proliferation where the intestinal tract could be the primary target site for a possible selective apoptotic stimulant against malignant cells.

\section{Technochemical aspects}

The pattern of ribonucleosides in mature milk varies only slightly throughout lactation. From experimental findings concerning changes in the contents of ribonucleosides in heat-treated milk (Ott \& Schlimme, 1991; Schlimme et al. 1993, 1994, 1998; Martin et al. 1995, 1997, 1998) it can be concluded that the concentrations of cytidine, guanosine and inosine present in raw milk show a multifold increase in milk which has been subjected to thermization and holder pasteurization, whereas the adenosine level decreases. On the other hand, these enzyme- (e.g. adenosine deaminase, alkaline phosphatase) catalysed changes in the content of unmodified ribonucleosides in milk are not observed in milk samples after short- and longtime pasteurization, high temperature pasteurization, ultrahigh heating and sterilization. The changes in milk ribonucleoside contents found in these heating regions are mainly attributable to the catalytic activity of the milk enzymes in the course of the heating-up phase.

The level of m1Ado varies only slightly throughout lactation and was found in raw bulk milk to be $0.4 \mu \mathrm{mol} / \mathrm{l}$. m6Ado, which is not detectable under the $\mathrm{pH}$ and temperature conditions prevailing in thermally untreated milk (Ott \& Schlimme, 1991), is formed by a Dimrothrearrangement from $\mathrm{m} 1$ Ado as a function of heating time and temperature (Ott \& Schlimme, 1991; Schlimme et al. 1993, 1994; Martin et al. 1995). This rearrangement follows first order kinetics in the temperature range between $115^{\circ} \mathrm{C}$ and $150^{\circ} \mathrm{C}$ with a $z$-value of $26 \cdot 8^{\circ} \mathrm{C}$ and a $\mathrm{Q}_{10^{-}}$-value of 2.36 (Schlimme et al. 1994; Martin et al. 1997). The kinetic data found for this rearrangement agree quite well with those found for other thermally induced chemical reactions in milk, e.g. lactulose formation or thiamine loss.

It can be concluded from the viewpoint of dairy technology that these minor constituents are useful as chemical indicators to quantify adulterations of milk and milk products, e.g. thermal milk treatment and - not reviewed in this paper - to distinguish differently processed products, e.g. butter types (Schlimme et al. 1990b, 1996b, 1997a; Meisel et al. 1997).

\section{Conclusion}

Nucleosides and nucleotides belong to the group of natural bioactive substances in milk and colostrum that show a species-specific pattern. They are used by the body as exogenous trophochemical sources. The physiological capacity of these compounds in milk is given by the total potentially available amount of nucleosides. They are not only active as metabolites but, furthermore, seem to be important in the regulation of body functions. For example, they enhance antibody responses, contribute to iron absorption in the gut and influence long-chain polyunsaturated fatty acid synthesis in early life. Recent findings on effector properties in human cell model systems imply that modified nucleosides, in particular, inhibit cell proliferation and activate apoptosis. Owing to these biochemical properties of nucleosides and nucleotides, the European Commission allows the supplementation of infant and follow-on formula. Thus, the positive effects of breast milk are also made available to neonates that are not breastfed. Further studies are required to evaluate these findings on the regulative potential of milk nucleos(t)ides and of dietary nucleos(t)ides in general especially in the early stages of life.

\section{Acknowledgement}

E. Schlimme dedicates this work to his mentor Professor Friedrich Cramer.

\section{References}

Aronow B, Toll D, Patrick J, Hollingsworth P, McCartan K \& Ullman B (1986) Expression of a novel high-affinity purine nucleobase transport function in mutant mammalian T-lymphoblasts. Molecular and Cellular Biology 6, 2957-2962.

Barness LA \& Carver JD (1996) Nucleotides and the neonatal immune response. In Nutritional and Biological Significance of Dietary Nucleotides and Nucleic Acids, pp. 191-194 [A Gil and R Uauy, editors]. Granada: Abbott Laboratories.

Belt JA \& Noel LD (1988) Isolation and characterization of a mutant of L1210 murine leukemia deficient in nitrobenzylthioinosine - insensitive nucleoside transport. Journal of Biological Chemistry 263, 13819-13822.

Borek E (1971) tRNA and tRNA modification in differentiation and neoplasia. Cancer Research 31, 596-597.

Bronk JR \& Hastewell JG (1987) The transport of pyrimidines into tissue rings cut from rat small intestine. Journal of Physiology (London) 382, 475-488.

Carlson SE, Rhodes PG \& Fergusson MG (1986) Docosahexaenoic acid status of preterm infants at birth and following feeding with human or milk formula. American Journal of Clinical Nutrition 44, 789-804.

Carlson SE, Rhodes PG, Rao VS \& Goldgar DE (1987) Effect of fish oil supplementation on the n-3 fatty acid content of red blood cell membranes in preterm infants. Pediatric Research 21, 507-510.

Carver JD, Cox WI \& Barness LA (1990) Dietary nucleotide effects upon murine natural killer cell activity and macrophage 
activation. Journal of Parenteral and Enteral Nutrition 14, 1822.

Commission Directive (1996) 96/4/EC of 16 February 1996 amending Directive 91/321/EEC on infant formulae and followon formulae. Official Journal of the European Communities No L49, 12-16.

Darnowski JW, Holdridge C \& Handschumacher RE (1987) Concentrative uridine transport by murine spleenocytes: kinetics, substrate specificity and sodium dependency. Cancer Research 47, 2614-2619.

DeLucchi C, Pita ML, Faus MJ, Molina JA, Uauy R \& Gil A (1987) Effects of dietary nucleotides on the fatty acid composition of erythrocyte membrane lipids in term infants. Journal of Pediatric Gastroenterology and Nutrition 6, 568574.

Deutsch A \& Nilsson R (1960) Über die säurelöslichen Nucleotide der Frauenmilch. Hoppe-Seylers Zeitschrift Physiologische Chemie 321, 246-251.

Faelli A \& Esposito G (1970) Effect of inosine and its metabolites on intestinal iron absorption in the rat. Biochemical Pharmacology 19, 2551-2554.

Fairbairn HA \& Litt MA (1922) Nuclein in the treatment of pneumonia and other infections. Medical Times 8, 205-206.

Gehrke CW \& Kuo KCT (1990) Chromatographie and modification of nucleosides; part C: modified nucleosides in cancer and normal metabolism. In Journal of Chromatography Library, Vol. 45C, Amsterdam: Elsevier Publishers.

Gil A, Lozano E, DeLucchi C, Maldonado J, Molina JA \& Pita M (1988) Changes in the fatty acid profiles of plasma lipid fractions induced by dietary nucleotides in infants born at term. European Journal of Clinical Nutrition 42, 473-481.

Gil A, Pita M, Martinez A, Molina JA \& Sanchez-Medina F (1986) Effect of dietary nucleotides on the plasma fatty acids in at-term neonates. Human Nutrition Clinical Nutrition 40C, 185-195.

Gil A \& Sanchez-Medina F (1981a) Acid-soluble nucleotides of cow's, goat's and sheep's milks at different stages of lactation. Journal of Dairy Research 48, 35-44.

Gil A \& Sanchez-Medina F (1981b) The determination of acidsoluble nucleotides in milk by improved enzymatic methods: A comparison with the ion-exchange column chromatography procedure. Journal of the Science of Food and Agriculture 32, $1123-1131$.

Gil A \& Sanchez-Medina F (1982) Acid-soluble nucleotides of human milk at different stages of lactation. Journal of Dairy Research 49, 301-307.

Griffith DA \& Jarvis SM (1993) High-affinity sodium-dependent nucleobase transport in cultured renal epithelial cells (LLCPK1). Journal of Biological Chemistry 268, 20085-20090.

Groß H, Topp H, Heller-Schöch G \& Schöch G (1992) Modifizierte Ribonucleoside in Frauenmilch. Ernährungsumschau 39, 21.

Gutiérrez MM, Brett CM, Ott RJ, Hui AC \& Giacomini KM (1992) Nucleoside transport in brush-border membrane vesicles from human kidney. Biochimica et Biophysica Acta 1105, 1-9.

Gyorgy P (1971) Biochemical aspects of human milk. American Journal of Clinical Nutrition 24, 970-975.

Hickman JA (1992) Apoptosis induced by anticancer drugs. Cancer Metastasis Review 11, 121-139.

Janas LM \& Picciano MF (1982) The nucleotide profile of human milk. Pediatric Research 16, 659-662.

Jarvis SM (1989) Characterization of sodium-dependent nucleoside transport in rabbit intestinal brush-border membrane vesicles. Biochimica et Biophysica Acta 979, 132-138.

Jarvis SM (1996) Nucleoside and nucleobase transport in animal cells. In Nutritional and Biological Significance of Dietary
Nucleotides and Nucleic Acids, pp. 87-110 [A Gil and R Uauy, editors]. Granada: Abbott Laboratories.

Johke T \& Goto T (1962) Acid-soluble nucleotides in cow's and goat's milk. Journal of Dairy Science 45, 735-741.

Kobata A (1963) The acid-soluble nucleotides of milk. II. Isolation and identification of two novel uridine nucleotide oligosaccharide conjugates from human milk and colostrum. Journal of Biochemistry 53, 167-175.

Koletzko B, Schmidt E, Bremer HJ, Haug M \& Harzer G (1989) Effect of dietary long-chain polymers saturated fatty acids on the essential fatty acid status of premature infants. European Journal of Pediatrics 148, 669-675.

Larson BL (1976) Comparative production of $\beta$-lactoglobulin and orotic acid with lactose in bovine mammary cell cultures: effects of cell density and constituent inhibition. Journal of Dairy Science 59, 1881-1889.

Larson BL, Heary HL Jr \& Devery JE (1980) Immunoglobulin production and transport by the mammary gland. Journal of Dairy Science 63, 665-671.

Le Hir M \& Dubach UC (1985) Concentrative transport of purine nucleosides in Grush-border vesicles of rat kidney. European Journal of Clinical Investigation 15, 121-127.

Leach JL, Baxter JH, Molitor BE, Ramstack MB \& Masor ML (1995) Total potentially available nucleosides of human milk by stage of lactation. American Journal of Clinical Nutrition 61, 1224-1230.

Lee CW, Cheeseman CI \& Jarvis SM (1988) $\mathrm{Na}^{+}$- and $\mathrm{K}^{+}$dependent uridine transport in rat renal brush-border membrane vesicles. Biochimica et Biophysica Acta 942, 139-149.

Leist M \& Nicotera P (1997) Breakthroughs and views. The shape of cell death. Biochemical and Biophysical Research Communications 236, 1-9.

Leleiko NS, Bronstein AD, Baliga BS \& Munro HN (1983) De novo purine nucleotide synthesis in the rat small and large intestines. Effect of dietary protein and purines. Journal of Pediatric Gastroenterology and Nutrition 2, 313-319.

Leleiko NS, Bronstein AD \& Munro HN (1979) Effect of dietary purines on de novo synthesis of purine nucleotides in the small intestinal mucosa. Pediatric Research 13, 403.

Leleiko NL, Martin BA, Walsh M, Kazlow P, Rabinowitz S \& Sterling K (1987) Tissue-specific gene expression results from a purine- and pyrimidine-free diet and 6-mercaptopurine in the rat small intestine and colon. Gastroenterology 93, 1014-1020.

Manson W (1956) Acid-soluble nucleotides of lactating mammary gland. Biochimica et Biophysica Acta 19, 398-399.

Martin SJ, Green DR \& Cotter TG (1994) Dicing with death: dissecting the components of the apoptosis machinery. Trends Biochemical Science 19, 26-30.

Martin D, Kiesner C, Lorenzen PChr \& Schlimme E (1998) Adenosin-Desaminase (EC 3.5.4.4): Ein potentieller Hitzeindikator zur Unterscheidung von kurzzeit- und hocherhitzter Konsummilch. Kieler Milchwirtschaftliche Forschungsberichte 50, 225-233.

Martin D, Kiesner C \& Schlimme E (1995) Kinetische Analyse der Dimroth-Umlagerung des 1-Methyladenosins in Milch unter Temperatur-Zeit-Bedingungen des Sterilbereichs. Kieler Milchwirtschaftliche Forschungsberichte 47, 75-86.

Martin D, Kiesner C \& Schlimme E (1997) Ribonucleosides: chemical parameters for controlling the heat treatment of milk. Nahrung/Food 541, 258-267.

McMillan JA, Oski FA, Lourie G, Tomarelli RM \& Landau SA (1977) Iron absorption from human milk, simulated human milk, and proprietary formulas. Pediatrics 60, 896-900.

Meisel H, Günther S, Martin D \& Schlimme E (1998) Apoptosis induced by modified ribonucleosides in human cell culture systems. FEBS Letters 433, 265-268.

Meisel H, Hartmann R, Martin D \& Schlimme E (1999) 
Modulating effects of adenosine and modified adenine nucleosides on human cells (HL-60). Nahrung/Food 43, 213-215.

Meisel H, Lorenzen PChr, Martin D \& Schlimme E (1997) Chemometric differentiation of butter types by analysis of compositional parameters with neural networks. Nahrung/Food 41, 75-80.

Molina JA, Romera JM \& Gil A (1996) Nucleotides and nucleic acids in human milk. In Nutritional and Biological Significance of Dietary Nucleotides and Nucleic Acids, pp. 63-67 [A Gil and R Uauy, editors]. Granada: Abbott Laboratories.

Ohyanogi H, Nishimatsu S, Nomura H \& Kawamura M (1996) Effect of nucleotides and nucleosides on cell growth in vitro and in vivo. In Nutritional and Biological Significance of Dietary Nucleotides and Nucleic Acids, pp. 145-168 [A Gil and R Uauy, editors]. Granada: Abbott Laboratories.

Ott FG \& Schlimme E (1991) Thermisch induzierte Bildung von N6-Methyladenosin in Milch. Kieler Milchwirtschaftliche Forschungsberichte 43, 213-217.

Pickering LK, Granoff DM, Erickson JR, Masor ML, Cordle LT, Schaller JP, Winship TR, Paule CL \& Hilty MD (1998) Modulation of the immune system by human milk and infant formula containing nucleotides. Pediatrics 101, 242-249.

Pita ML, Fernandez MR, De-Lucchi C, Medina A, MartinezValverde A, Uauy R \& Gil A (1988) Changes in the fatty acids pattern of red blood cell phospholipids induced by type of milk, dietary nucleotide supplementation, and postnatal age in preterm infants. Journal of Pediatric Gastroenterology and Nutrition 7, 740-747.

Plagemann PGW \& Wohlheuter RM (1984) Hypoxanthine transport in mammalian cells: cell type-specific differences in sensitivity to inhibition by dipyridamole and uridine. Journal of Membrane Biology 81, 255-262.

Putnam JC, Carlson SE, DeVoe PW \& Barness LA (1982) The effect of variations in dietary fatty acids on the fatty acid composition of erythrocyte phosphatidylcholine and phosphatidylethanolamine in human infants. American Journal of Clinical Nutrition 36, 106-114.

Raezke K-P, Frister H, Pabst K \& Schlimme E (1988) Ribonucleoside als minore Milchinhaltsstoffe. II. Untersuchung des Ribonucleosidmusters in Rohmilch während der zweiten Hälfte der Lactationsphase. Milchwissenschaft 43, 294-298.

Raezke K-P \& Schlimme E (1990) Ribonucleoside in Milch: Charakterisierung und Bestimmung des Konzentrationsprofils dieser minoren Komponenten über eine Laktationsperiode. Zeitschrift für Naturforschung 45c, 655-662.

Robertson LE, Chubb S, Meyn RE, Story M, Ford R, Hittelman WN \& Plunkett W (1993) Induction of apoptotic cell death in chronic lymphocytic leukemia by 2 -chloro2 'deoxyadenosine and 9- $\beta$-D-arabinosyl-2-fluoroadenine. Blood 81, 143-150.

Sanchez-Medina F \& Gil A (1996) Dietary nucleotides and polyunsaturated fatty acid metabolism. In Nutritional and Biological Significance of Dietary Nucleotides and Nucleic Acids, pp. 111-120 [A Gil and R Uauy, editors]. Granada: Abbott Laboratories.

Sanchez-Pozo A \& Gil A (1996) Influence of dietary nucleotides on neonatal lipoprotein metabolism. In Nutritional and Biological Significance of Dietary Nucleotides and Nucleic Acids, pp. 133-144 [A Gil and R Uauy, editors]. Granada: Abbott Laboratories.

Sanchez-Pozo A, Pita ML, Martinez A, Molina JA, SanchezMedina F \& Gil A (1986) Effects of dietary nucleotides upon lipoprotein pattern of newborn infants. Nutrition Research 6 , 763-771.

Schlimme E \& Boos K-S (1990) Ribonucleosides in body fluids on-line chromatographie clean-up and analysis by a columnswitching technique. In Modified Nucleosides in Cancer and
Normal Metabolism, pp. C115-C145 [CW Gehrke and KC Kuo, editors]. Journal of Chromatography Library, 45C, Amsterdam: Elsevier.

Schlimme E, Boos K-S, Frister H, Pabst K, Raezke K-P \& Wilmers B (1986) Gruppenselektive Hochleistungsflüssigkeitschromatographie von Ribonucleosiden in Milch. Milchwissenschaft 41, 757-762.

Schlimme E, Boos K-S, Schwarzenau E, Frister H, Ott FG, Raezke K-P \& Wilmers B (1990a) Dual column HPLC analysis of modified ribonucleosides as urinary pathobiochemical markers in clinical research. Nucleosides \& Nucleotides $\mathbf{9}$, 407-410.

Schlimme E, Kiesner C, Lorenzen PChr \& Martin D (1998) Influence of heat treatment of milk on the activities of the indigenous milk enzymes alkaline phosphatase and adenosine deaminase. International Dairy Federation-Bulletin No. 332, (Commission B), 25-31.

Schlimme E, Lorenzen PChr, Martin D, Meisel H \& Thormählen K (1997a) Differenzierung von Buttersorten. Kieler Milchwirtschaftliche Forschungsberichte 49, 135-145.

Schlimme E, Lorenzen PChr, Martin D \& Thormählen K (1996b) Analytical differentiation of butter types by specific compositional parameters of the aqueous butter phase. Milchwissenschaft 51, 139-143.

Schlimme E \& Martin D (1999) Nucleotid-Supplementierung von Säuglingsnahrung. Kieler Milchwirtschaftliche Forschungsberichte 51, 215-224.

Schlimme E, Martin D, Meisel H, Schneehagen K, Hoffmann S, Sievers E, Ott FG \& Raezke K-P (1997b) Species-specific composition pattern of milk ribonucleosides and -nucleotides: chemical and physiological aspects. Kieler Milchwirtschaftliche Forschungsberichte 49, 305-326.

Schlimme E, Ott FG \& Kiesner C (1994) Reaction kinetics of heat induced formation of N6-methyladenosine in milk. International Dairy Journal 4, 617-627.

Schlimme E, Ott FG, Kiesner C \& Biewendt HG (1993) Heatdependent generation of modified ribonucleosides in milk in the temperature range $40-150^{\circ} \mathrm{C}$. International Dairy Federation Special Issue 9303, 52-66.

Schlimme E, Raezke K-P \& Ott FG (1991) Ribonucleosides as minor milk constituents. Zeitschrift für Ernährungswissenschaft 30, $138-152$.

Schlimme E, Raezke K-P, Ott FG \& Schneehagen K (1996a) Ribonucleosides as minor milk constituents: Dependence of nucleoside composition on mammalian species and lactation stage. In Nutritional and Biological Significance of Dietary Nucleotides and Nucleic Acids, pp. 69-86 [A Gil and R Uauy, editors]. Granada: Abbott Laboratories.

Schlimme E \& Schneehagen K (1995) Ribonucleosides in human milk -Concentration profiles of these minor constituents as a function of the nursing time. Zeitschrift für Naturforschung 50c, 105-113.

Schlimme E, Schneehagen K \& Ott FG (1990b) Differenzierung von Buttersorten mit Hilfe der Butterserum-Ribonucleoside. Milchwissenschaft 45, 654-657.

Schneehagen K \& Schlimme E (1992) Ribonucleoside: Minore Inhaltsstoffe der Humanmilch. Kieler Milchwirtschaftliche Forschungsberichte 44, 67-74.

Schwarzenau E, Schlimme E, Boos K-S, Wilmers B, Raezke K-P, Ott FG, Hilfrich J \& Schneider J (1990) Ribonucleosidausscheidungsmuster bei Mammakarzinompatientinnen. Tumor Diagnostik \& Therapie 11, 198-203.

Souci SW, Fachmann W \& Kraut H (1994)In Food Composition and Nutrition Tables, 5th edition. Boca Raton: CRC Press, Medpharm Scientific Publishers.

Sugawara M, Sato N, Nakano T, Idota T \& Nakajima I (1995) 
Profile of nucleotides and nucleosides in human milk. Journal of Nutritional Science and Vitaminology 41, 409-418.

Tiemeyer W, Stohrer M \& Giesecke D (1984) Metabolites of nucleic acids in bovine milk. Journal of Dairy Science 67, 723728.

Topp H, Groß H, Heller-Schöch G \& Schöch G (1993) Determination of N6-threoninocarbonyladenosine N2,N2dimethylguanosine, pseudouridine and other ribonucleosides in human breast milk. Nucleosides \& Nucleotides 12, 585-596.

Uauy R (1989) Dietary nucleotides and requirements in early life. In Textbook of Gastroenterology and Nutrition in Infancy, 2nd edition, pp. 265-280 [E Lebenthal, editor]. New York: Raven Press.

Uau R, Quan R \& Gil A (1996) Nucleotides in infant nutrition. In Nutritional and Biological Significance of Dietary Nucleotides and Nucleic Acids, pp. 169-180 [A Gil and R Uauy, editors]. Granada: Abbott Laboratories.

Uauy R, Stringel G, Thomas R \& Quan R (1990) Effect of dietary nucleosides on growth and maturation of the developing gut in the rat. Journal of Pediatric Gastroenterology and Nutrition 10, 497-503.

Ullman B, Patrick J \& McCartan K (1987) Expression of the highaffinity purine nucleobase transporter in mutant mouse S49 cells does not require a functional wild-type nucleosidenucleobase transporter. Molecular and Cellular Biology 7, 97-103.

Van Buren CT \& Rudolph F (1997) Dietary nucleotides: A conditional requirement. Nutrition 13, 470-472.

Vijayalakshmi D, Dagino L, Belt JA, Gati WP, Cass CE \& Paterson ARP (1992) Cells express equilibrative, inhibitorsensitive nucleoside transport activity and lack two parental nucleoside transport activities. Journal of Biological Chemistry 267, 16951-16956.

Williams TC \& Jarvis SM (1991) Multiple sodium dependent nucleoside transport systems in bovine renal brush-border membrane vesicles. Biochemical Journal 274, 27-33.

Wright SC, Zhong J \& Larrick JW (1994) Inhibition of apoptosis as a mechanism of tumor promotion. The FASEB Journal 8 , 654-660.

Ziv G \& Heavner JE (1984) Permeability of the blood-milk barrier to methylene blue in cows and goats. Journal of Veterinary Pharmacology and Therapeutics 7, 55-59.

Ziv G \& Sulman FG (1975) Absorption of antibiotics by the bovine udder. Journal of Dairy Science 58, 1637-1644. 